\title{
Synthesis and Characterization of Carbon Nano Kajal
}

\author{
Swapna MS, Pooja V Menon, Anamika S Anand, Soumya S and Sankararaman S* \\ Department of Optoelectronics, University of Kerala, India
}

Submission: April 14, 2017; Published: May 30, 2017

*Corresponding author: Sankararaman S, Department of Optoelectronics, University of Kerala, Kariavattom, Kerala, 695581, India, Email: drssraman@gmail.com

\begin{abstract}
Carbon nanoparticles are of considerable interest today because of their unique physical and biological properties. There are several methods of preparation of Carbon Nanoparticles (CNP) with high efficacy and low toxicity. In this paper we describe a simple low cost synthesis of carbon nanoparticle. We present a simple method for the synthesis of carbon nanoparticles from the controlled combustion of coconut oil and ghee. The antibacterial property of CNP enables its use in kajals. The FESEM image of the sample prepared exhibit carbon nanoparticles of size less than $50 \mathrm{~nm}$
\end{abstract}

\section{Introduction}

Nowadays carbon based nanoparticles have gained great attention in many research areas because of their unique physical and chemical properties. Various carbon-derived nano materials such as fullerenes, carbon nano tubes (CNTs), graphitic nano fibers (GNFs), graphene etc. exhibit remarkable optical and electronic properties, which have been exploited for various applications such as optoelectronics, chemical sensing, biological labeling, etc. [1]. Nanoparticles with dimensions ranging from 1-100nm exhibit interesting physical and chemical properties. Nanoparticles are found in amorphous or crystalline form. The nanoparticles have become most suitable in the field of medicine because biological processes also occur in the nano scale. Carbon is one of the most abundant elements in nature. When the size of carbon particles decreases into nano scale range the antibacterial action increases. This is due to their large surface area and the presence of large number of atoms near the surface [2]. It has been found that carbon nanoparticles damage the membranes in bacteria due to an oxidative stress $[3,4]$. In this work we synthesized carbon nanoparticles in a simple method by the incomplete combustion of coconut oil. We collected the nanoparticles in a glass plate. The prepared carbon nanoparticles are used for making kajals.

The use of nanoparticles in cosmetics is not new. Black soot and mineral powders have been used as cosmetics since thousands of years ago in ancient India and Egypt. The properties of nanoparticles such as high penetration into skins, antibacterial action, optical properties make them suitable for cosmetic industry. In this paper we have made an attempt to synthesize carbon nanoparticles that can be used for making kajals to give protection to eyes. Here we prepared CNP by collecting soot particles at a height formed during the incomplete combustion of coconut oil. The kajals available in the market nowadays contains harmful chemicals that cause irritation to our eyes. We propose a new kajal incorporated with carbon nanoparticles named as nano-kajal that has no side effects or irritation to our eyes.

Hydrocarbons are organic compounds consisting of carbon and hydrogen elements only. At present, a lot of hydrocarbons are used as precursors in several methods of preparation of nanoparticles. Simplest form of hydrocarbons, i.e. saturated hydrocarbons contains only single bonds. The unsaturated forms of them have double or triple bonds in their structure and aromatic hydrocarbons have at least one aromatic ring $[5,6]$.

Combustion, also known as burning, is the basic chemical process of releasing energy from a fuel and air mixture. This combustion method belongs to the class of bottom-up method of nanoparticle synthesis, where we require a combustion chamber of high temperature and pressure.

\section{Materials and Methods}

The carbon nanoparticles are synthesized from the incomplete combustion of coconut oil and ghee. A glass plate cleaned with acetone is used for depositing CNP. Cotton wick is used to make the flame. The carbon particles are collected on a glass plate placed at a distance of $50 \mathrm{~cm}$ from the lamp wick. The experimental setup is shown in (Figure 1). The soot particles collected on the glass plate were analyzed by FESEM. In order to understand the morphology of CNP thus formed from various oils we conducted the study with ghee. The CNPs formed from coconut oil and ghee under identical condition are studied. The soot is purified by liquid phase oxidation method using a mixture 
of $\mathrm{H}_{2} \mathrm{SO}_{4}$ and $\mathrm{HNO}_{3}$. Then it is quenched with ice cooled water and base neutralized by $\mathrm{NaOH}$ [7].

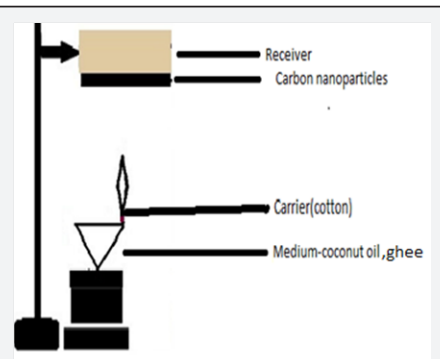

Figure 1: Schematic for the collection of soot particles.

\section{Results and Discussion}

\section{FESEM and EDS analysis}

Carbon nanoparticles are prepared from soot particle formed by the incomplete combustion of coconut oil and ghee are subjected to morphological characterization by Nova Nano Field Emission Scanning Electron Microscopy (FESEM). Scanning electron microscopy is used to analyze the morphology of the carbon nanoparticles and is shown in (Figure $2 \& 3$ ). The FESEM image shows CNP of average size less than $50 \mathrm{~nm}$. The Energy Dispersive Spectra of the diesel soot particles are taken, to obtain the elemental compositions.

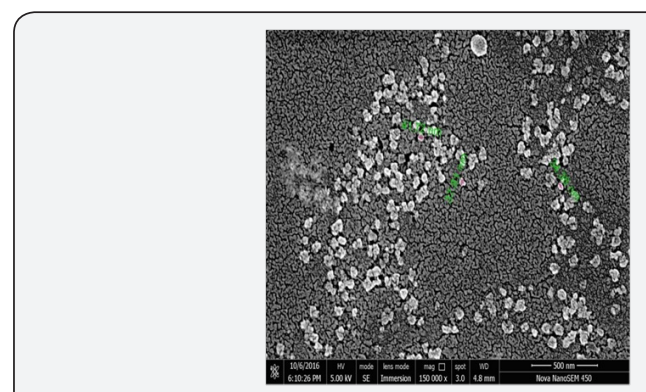

Figure 2: FESEM image of carbon nanoparticles from coconut oil (×150 000 magnifications).

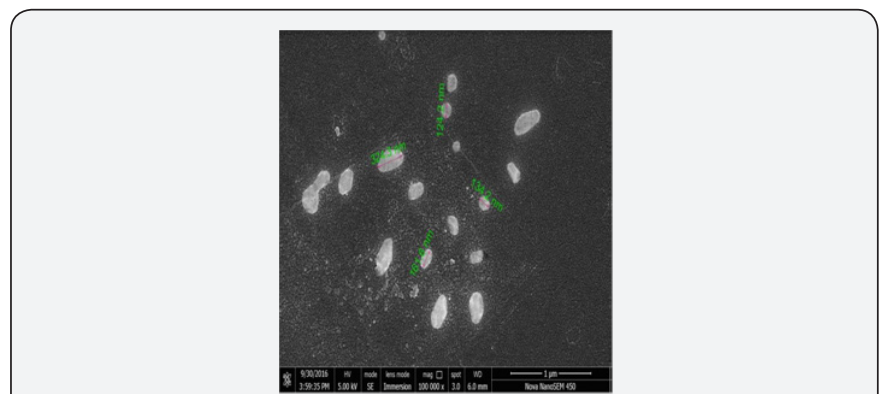

Figure 3: FESEM image of carbon nanoparticles from ghee (×100 000 magnifications).

The particles formed are polygonal in shape. Under identical conditions we could reproduce CNPs of identical shape and size. The SEM image shows uniform particle size and distribution of carbon nanoparticles. The SEM image of the carbon particles obtained from ghee was comparatively bigger $(\sim 150 \mathrm{~nm})$.

\section{UV-visible spectroscopy}

The UV-Visible spectrum of the sample is recorded using Jasco V 550 UV-Visible spectrophotometer and is shown in (Figure 4). The spectrum shows a peak at $247 \mathrm{~nm}$ that arises from the $\Pi-\Pi^{*}$ transition of $\mathrm{C}-\mathrm{C}$ and $\mathrm{C}=\mathrm{C}$ bonds in $\mathrm{sp}^{2}$ hybrid region. The peaks at $278 \mathrm{~m}-290 \mathrm{~nm}$ region is due to $n-\pi^{*}$ transition of the $\mathrm{C}=\mathrm{O}$ bond of the $\mathrm{sp}^{3}$ hybrid region [8]. These features indicate Single walled carbon nanotubes (SWCNTs) in the samp.

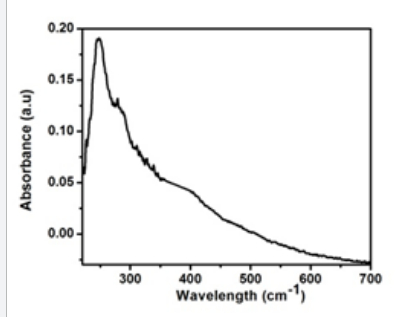

Figure 4: UV- Visible spectrum of soot obtained from coconut oil.

\section{Conclusion}

In the present work we describe the synthesis of carbon nanoparticles from the controlled combustion of coconut oil and ghee. The antibacterial property of CNP enables its use in kajals that were well understood by ancestors. The traditional method could give good quality CNPs when collected at a height of $50 \mathrm{~cm}$. The UV-Visible spectrum reveals the possibility of single walled carbon nano tubes (SWCNTs) that can be used as a low cost material for potential applications in fuel cell, carbon nano capacitors etc.

\section{References}

1. Mauricio T (2003) Science and Technology of the Twenty-First Century: Synthesis, Properties, and Applications of Carbon Nanotubes. Rev Mater Res 33: 419-501.

2. Sheena V, Sunny K, Soumya J (2013) Antimicrobial Activity of Carbon Nanoparticles Isolated from Natural Sources against Pathogenic Gram-Negative and Gram-Positive Bacteria. Journal of Nanoscience 2013(2013): p. 5.

3. Gurunathan S, Han JW, Dayem AA, Eppakayala V, Kim JH (2012) Oxidative stress-mediated antibacterial activity of graphene oxide and reduced graphene oxide in Pseudomonas aeruginosa. Int J Nanomedicine 7: 5901-59014.

4. Pacurar M, Qian Y, Fu W, Schwegler-Berry D, Ding M, et al. (2012) Cell permeability, migration, and reactive oxygen species induced by multiwalled carbon nanotubes in human Microvascular endothelial cells. J Toxicol Environ Health A 75(2): 112-128.

5. Santana DWEA, Sepulveda MP, Barbiera PJS (2007) J Fuel 86: 911.

6. Al-Ghouti M, Al-Degs Y, Mustafa F (2010) J Fuel 89: 193.

7. Hussain S, Jha P, Chouksey A, Raman R, Islam SS et al. (2011) Spectroscopic Investigation of Modified Single Wall Carbon Nanotube (SWCNT). J Mod Phys 2(6): 538-543.

8. Bichitra NS, Balasubramanian K, Subramanian A (2014) RSC Adv 4: 11331. 
This work is licensed under Creative Commons Attribution 4.0 Licens DOI: 10.19080/JOJMS.2017.01.555566
Your next submission with Juniper Publishers will reach you the below assets

- Quality Editorial service

- Swift Peer Review

- Reprints availability

- E-prints Service

- Manuscript Podcast for convenient understanding

- Global attainment for your research

- Manuscript accessibility in different formats

( Pdf, E-pub, Full Text, Audio)

- Unceasing customer service

Track the below URL for one-step submission https://juniperpublishers.com/online-submission.php 